Review

\title{
Selective Induction of Cancer Cell Death by Targeted Granzyme B
}

\author{
Pranav Oberoi ${ }^{\dagger}$, Robert A. Jabulowsky ${ }^{\dagger}$ and Winfried S. Wels * \\ Chemotherapeutisches Forschungsinstitut Georg-Speyer-Haus, 60596 Frankfurt am Main, Germany; \\ E-Mails: oberoi@em.uni-frankfurt.de (P.O.); r.jabulowsky@web.de (R.A.J.)
}

$\dagger$ These authors contributed equally to this work.

* Author to whom correspondence should be addressed; E-Mail: wels@em.uni-frankfurt.de; Tel.: +49-69-63395-188; Fax: +49-69-63395-189.

Received: 24 December 2012; in revised form: 18 February 2013 / Accepted: 20 February 2013 / Published: 27 February 2013

\begin{abstract}
The potential utility of immunotoxins for cancer therapy has convincingly been demonstrated in clinical studies. Nevertheless, the high immunogenicity of their bacterial toxin domain represents a critical limitation, and has prompted the evaluation of cell-death inducing proteins of human origin as a basis for less immunogenic immunotoxin-like molecules. In this review, we focus on the current status and future prospects of targeted fusion proteins for cancer therapy that employ granzyme B $(\mathrm{GrB})$ from cytotoxic lymphocytes as a cytotoxic moiety. Naturally, this serine protease plays a critical role in the immune defense by inducing apoptotic target cell death upon cleavage of intracellular substrates. Advances in understanding of the structure and function of $\mathrm{GrB}$ enabled the generation of chimeric fusion proteins that carry a heterologous cell binding domain for recognition of tumor-associated cell surface antigens. These hybrid molecules display high selectivity for cancer cells, with cell killing activities similar to that of corresponding recombinant toxins. Recent findings have helped to understand and circumvent intrinsic cell binding of GrB and susceptibility of the enzyme to inhibition by serpins. This now allows the rational design of optimized GrB derivatives that avoid sequestration by binding to non-target tissues, limit off-target effects, and overcome resistance mechanisms in tumor cells.
\end{abstract}

Keywords: granzyme B; cancer therapy; epidermal growth factor receptor; ErbB2; HER2; transforming growth factor $\alpha$; single-chain Fv antibody; recombinant fusion protein 


\section{Introduction}

Monoclonal antibodies are well established as targeted therapeutics for the treatment of cancer, and an increasing number of such reagents are in clinical use. Prominent examples include the anti-CD20 antibody rituximab (Rituxan/MabThera) [1], the epidermal growth factor receptor (EGFR)-specific antibody cetuximab (Erbitux), and the ErbB2 (HER2)-specific antibody trastuzumab (Herceptin) [2,3]. Nevertheless, responses could not be achieved in all patients with cancers expressing high levels of the respective target antigens, and in a significant proportion of patients, initial responses are followed by the development of resistance despite continued antigen expression [4,5]. This suggests that patientand tumor-specific factors such as limited recruitment of endogenous immune effector mechanisms and activation of alternative signaling pathways can influence treatment outcome. In contrast to regular antibodies, protein conjugates and recombinant fusion proteins that link antibody- or ligand-mediated recognition of cancer cells with a potent cytotoxic effector function can achieve their antitumoral activity independent of the signaling capabilities of the target antigen, and do not require endogenous immune effector functions such as antibody-dependent cell-mediated cytotoxicity (ADCC) or complement fixation. Hence, such targeted therapeutics may constitute a valuable treatment option, in particular in cases where current antibody therapies are ineffective.

Antibody-toxins, also termed immunotoxins, were initially derived by chemically coupling bacterial or plant toxins to monoclonal antibodies specific for molecules on the surface of tumor cells. The elucidation of the molecular structure of bacterial toxins such as Pseudomonas exotoxin A (ETA, PE), and the development of recombinant antibody formats have allowed to miniaturize these molecules through recombinant DNA techniques, and to produce them as single polypeptides in large quantities and of consistent quality in bacteria [6]. Recombinant ETA-based toxins are derived by replacing the toxin's N-terminal cell binding domain with a heterologous function for cell recognition, such as a natural peptide ligand or a single-chain $\mathrm{Fv}(\mathrm{scFv})$ antibody fragment $[7,8]$. This basic principle has been applied successfully for antibody-toxins targeted to many different tumor-associated surface antigens including EGFR, ErbB2, mesothelin, and differentiation antigens like CD22, some of which have entered clinical development [9-11]. Nevertheless, while clinical trials with antibody-toxins for the treatment of hematologic malignancies have yielded impressive response rates, reports on successful application of such molecules in patients suffering from cancers of epithelial origin are still rare $[9,12,13]$. This is at least in part due to the type of target antigens available. Normal expression of target receptors such as CD22 is restricted to a defined population of differentiated cells, thereby limiting potential adverse effects, whereas epithelial antigens targeted for therapy usually display significantly enhanced expression in tumors, but might also be present at varying levels on different normal tissues. Consequently, for recombinant toxins targeted to epithelial tumor antigens the therapeutic index, i.e., the difference between the minimum effective dose and the maximum tolerated dose might be smaller.

In principle, repeated treatment cycles or continuous therapy for a prolonged time period may overcome this problem. This, however, is hampered by the high immunogenicity of current antibodytoxins, resulting in rapid development of neutralizing antibodies against their toxin portion [8,9]. Different approaches have been proposed to reduce immunogenicity, including combined treatment with immunosuppressive reagents, chemical modification of the toxin moiety with polyethylene glycol 
(PEGylation), and elimination of dominant $\mathrm{B}$ and $\mathrm{T}$ cell epitopes [6,8]. Alternatively, employing a cytotoxic protein of human origin as an effector function in immunotoxin-like molecules may be considered a straightforward way to circumvent the problem of high immunogenicity. Target cell killing by bacterial toxins such as ETA is mediated by the inhibition of protein synthesis, followed by the induction of apoptosis via indirect mechanisms [14,15]. Consequently, human molecules that transmit strong pro-apoptotic signals are prime candidates for the development of targeted fusion proteins for cancer therapy [16]. Different strategies have been proposed to exploit the process of cellular self-destruction for the ordered elimination of tumor cells, including the fusion of cell targeting domains to cell death inducing cytokines of the tumor necrosis factor family [17] or pro-apoptotic members of the Bcl-2 protein family $[18,19]$. These molecules function upstream in the apoptosis cascade, and their activity may be affected by reduced sensitivity of cancer cells to pro-apoptotic signals [20]. Hence, also human pro-apoptotic effectors have been employed to develop immunotoxinlike molecules that act at late stages of the apoptotic signaling cascade and can affect multiple pathways simultaneously. These include apoptosis inducing factor (AIF) and granzyme B (GrB) [21-25]. Thereby the serine protease $\mathrm{GrB}$, similar to protein toxins, modifies its substrates enzymatically, which allows amplification of its effects and can result in cytotoxicity even at low enzyme concentrations in the target cell cytosol. In this review, we focus on the current status and future prospects in the development of targeted GrB fusion proteins, with special emphasis on molecules directed to cancer cells overexpressing the growth factor receptors EGFR or ErbB2.

\section{Granzyme B Fusion Proteins for Targeted Cancer Therapy}

\subsection{Induction of Programmed Cell Death by the Serine Protease Granzyme B}

Granzyme B $(\mathrm{GrB})$ is naturally expressed by cytotoxic T-lymphocytes (CTL) and natural killer (NK) cells. The serine protease plays a crucial role in the immune defense against virus-infected and malignant cells by inducing apoptotic target cell death upon cleavage of intracellular substrates [26]. Initially, GrB is produced as an inactive precursor protein. This pre-pro-GrB carries an $\mathrm{N}$-terminal signal peptide directing packaging of the protein into secretory granules. Subsequent removal of the activation dipeptide Gly-Glu by the cysteine protease cathepsin $\mathrm{C}$ generates the enzymatically active form of $\mathrm{GrB}$ of approximately $32 \mathrm{kDa}$ [27], which is stored together with other granzymes and perforin in the dense core of lytic granules [28]. Following target recognition and effector cell activation, the lytic granules are polarized towards the immunological synapse, where they fuse with the plasma membrane and release their contents into the synaptic cleft between effector and target cell [29,30]. After its release, GrB enters target cells with the help of the pore-forming protein perforin, and rapidly induces apoptosis via caspasedependent and caspase-independent mechanisms [31]. The exact mechanisms of perforin pore formation and perforin-mediated GrB entry are still not fully understood. Recent studies indicate that perforin monomers released into the synaptic cleft bind to the target cell membrane, oligomerize, and undergo a major conformational rearrangement to form transmembrane pores [32,33]. Initially, it was thought that perforin pores may allow direct diffusion of GrB into the target cell cytosol. More recently, it has been suggested that pore-formation triggers membrane repair by an endocytic mechanism that facilitates co-internalization of perforin and $\mathrm{GrB}$ into vesicular compartments, followed by perforin-mediated 
endosomolysis and release of GrB into the cytosol [34,35] (Figure 1a). For recombinant human GrB expressed in mammalian cells also uptake independent of perforin has been described, which required binding to cell surface-bound heat shock protein 70 (Hsp70) and Hsp70-mediated internalization [36,37].

Figure 1. Cellular uptake of granzyme B and targeted granzyme B fusion proteins. (a) Perforin monomers released into the synaptic cleft bind to the target cell membrane, oligomerize, and undergo conformational rearrangement to form transmembrane pores. These may allow direct diffusion of $\mathrm{GrB}$, or trigger co-internalization of perforin and $\mathrm{GrB}$ into vesicular compartments, followed by perforin-mediated endosomolysis and release of GrB into the cytosol [34,35]. (b) Targeted GrB derivatives specifically interact with tumorassociated cell surface antigens such as EGFR or ErbB2 via their heterologous cell binding domain. Receptor-mediated endocytosis then results in uptake into endosomes. Efficient endosome release and translocation to the cytosol can be achieved by addition of an endosomolytic activity such as chloroquine $[23,38]$.

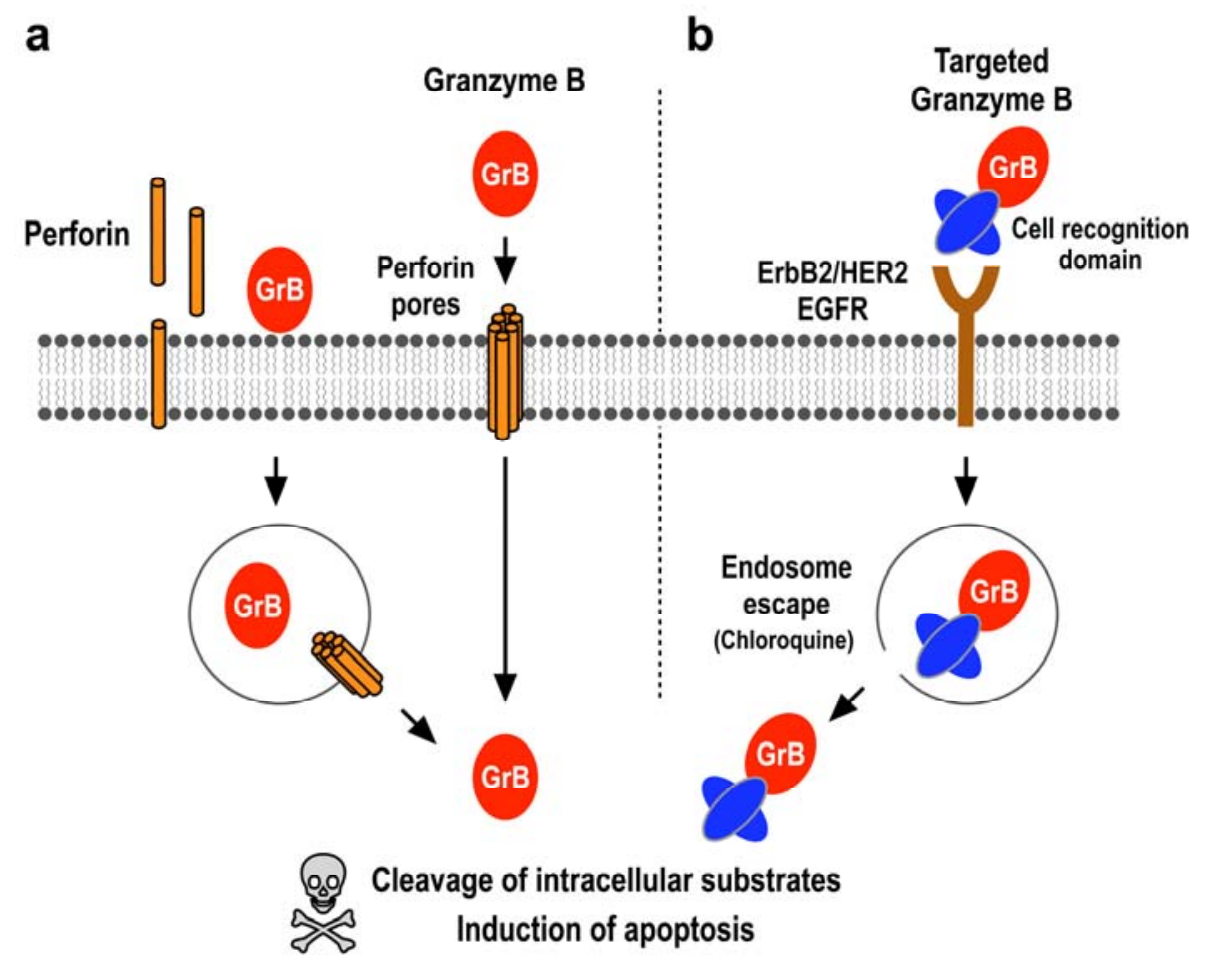

While cell death-inducing cytokines of the tumor necrosis factor family such as FASL and TRAIL require intact receptor systems and downstream signaling pathways to induce activation of initiator and effector caspases, cytosolic GrB can activate the apoptosis machinery directly and at different levels. This ensures induction of cell death even if one pathway is blocked [39]. GrB shares the substrate specificity of caspases, and cleaves its target proteins C-terminal of specific aspartate residues [40]. Important GrB substrates include caspase-3 and other initiator and effector caspases [41], as well as central caspase substrates such as the BH3-only protein Bid [42,43], and the inhibitor of caspaseactivated DNase (ICAD) [44,45]. In addition, GrB directly cleaves components of the cytoskeleton [46], lamin B [47], PARP [48], and proteins involved in cellular homeostasis and stress response [39]. 


\subsection{Expression Systems for Production of Granzyme B in Recombinant Form}

The availability of $\mathrm{GrB}$ in recombinant form is an important prerequisite for functional analysis of the protein, and essential for application of $\mathrm{GrB}$ as a therapeutic effector molecule. Thereby the production of enzymatically active protein is complicated by the requirement to eliminate the pre-pro domains from $\mathrm{GrB}$ in order to generate the free N-terminus of the mature molecule [27,49]. Large amounts of $\mathrm{GrB}$ and targeted $\mathrm{GrB}$ derivatives could be produced in E. coli as inactive precursors fused to heterologous N-terminal protein domains such as glutathione-S-transferase (GST), requiring refolding and additional in vitro cleavage with proteolytic enzymes of purified recombinant proteins [50-52]. Similarly, GrB and targeted GrB were expressed as inactive precursor proteins in mammalian cells for in vitro activation via cleavage of a synthetic enterokinase site within the molecule [53,54]. Recently, an interesting approach for the generation of self-activating GrB in E. coli was also reported [52]. Thereby the GrB-specific cleavage site IEPD was introduced between GrB and a heterologous $\mathrm{N}$-terminal prodomain, but so far, this approach has only been demonstrated to function for wildtype GrB not fused to a cell targeting ligand.

As a basis for subsequent studies on immunotoxin-like fusion proteins harboring GrB as an effector domain, we established a eukaryotic expression system utilizing the methylotrophic yeast Pichia pastoris for the production of human GrB in secreted, enzymatically active form [49]. Pichia pastoris is well established for the expression of secreted proteins [55], and had previously been employed to generate recombinant $\mathrm{GrB}$ from different mammalian species [56,57]. We fused amino acid residues 21 to 247 of $\mathrm{GrB}$ to the yeast $\alpha$-factor signal peptide, which is removed in the secretory pathway by the Pichia protease kexin, resulting in recombinant protein with the free N-terminus of mature human $\mathrm{GrB}$ released into the culture supernatant. In contrast to production of $\mathrm{GrB}$ in bacterial expression systems, the final product was glycosylated and did not require further refolding and/or proteolytic activation in vitro. Single-step purification by immobilized metal affinity chromatography (IMAC) utilizing a C-terminal polyhistidine tag attached to the GrB sequence yielded 1 to $2 \mathrm{mg}$ of purified protein per liter of culture supernatant. Recombinant GrB from yeast cleaved natural and synthetic GrB substrates with kinetic constants similar to those of human GrB isolated from IL-2-activated lymphocytes [49]. Direct cytosolic delivery of GrB with a cationic lipid-based transduction reagent resulted in rapid induction of apoptotic cell death, demonstrating the preserved cell-death inducing capacity of the recombinant protein [49]. Alternatively, GrB was generated in Pichia pastoris as a fusion with an $\mathrm{N}$-terminal maltose binding protein (MBP) domain as a chaperone, resulting in enhanced levels of free GrB upon in vivo processing of a kexin-sensitive cleavage site [58].

\subsection{Tumor Cell-Specific Granzyme B Fusion Proteins}

GrB requires a correctly processed, free $\mathrm{N}$-terminus for enzymatic activity [49]. Hence, attachment of a heterologous cell binding domain to the $\mathrm{C}$-terminus of $\mathrm{GrB}$ allows to redirect the resulting fusion molecule to a tumor-associated cell surface antigen while retaining functionality of the serine protease (Figure 1b). Successful generation of a targeted GrB protein was first reported by the group of Rosenblum, who fused vascular endothelial growth factor (VEGF) 121 to GrB [22]. Upon bacterial expression and proteolytic activation in vitro, the fusion protein specifically eliminated endothelial 
cells expressing the FLK-1/KDR receptor, which may be employed to target the tumor vasculature. Likewise, GrB was fused to a scFv antibody fragment targeting the melanoma antigen gp240, resulting in rapid killing of antigen-positive target cells in vitro with an $\mathrm{IC}_{50}$ of $20 \mathrm{nM}$ [50], and growth delay of melanoma xenografts in a murine in vivo model [59]. Interestingly, in the latter case treatment with the GrB-scFv protein sensitized tumors to subsequent chemotherapy or ionizing irradiation. Targeted cytotoxicity in the absence of perforin was also achieved with an immunoconjugate of bacterially expressed and in vitro activated GrB linked via a disulfide bond to a dsFv antibody fragment specific for the Lewis Y carbohydrate antigen [51]. Depending on caspase-3 and target antigen expression by tumor cells, half-maximal killing was achieved in in vitro cytotoxicity assays after $48 \mathrm{~h}$ at concentrations of 35 to $98 \mathrm{nM}$, which compares to concentrations of 1.8 to $42 \mathrm{nM}$ for a corresponding Pseudomonas exotoxin A immunoconjugate under the same experimental conditions. For an in vitro activated GrB-scFv fusion protein targeting CD64-positive acute myeloid leukemia (AML) cells, also $\mathrm{IC}_{50}$ values in the nanomolar range were reported [53]. After 3 days of treatment, half-maximal killing of established AML cells was achieved at concentrations of 1.7 to $17 \mathrm{nM}$.

Following a strategy similar to the one outlined above for expression of recombinant wildtype GrB in Pichia pastoris, we generated chimeric GrB fusion proteins harboring at their C-terminus the EGFR ligand transforming growth factor (TGF) $\alpha$ or the ErbB2-specific scFv antibody fragment $\mathrm{scFv}(\mathrm{FRP} 5)$ for selective targeting to tumor cells [23]. Overexpression of EGFR and the closely related ErbB2 protein have been described for many tumors of epithelial origin, and have been shown to contribute to cellular transformation [3]. Importantly, these growth factor receptors are accessible from the extracellular space, making them attractive targets for monoclonal antibodies as well as antibodytoxins or recombinant toxins that employ natural peptide ligands for targeting $[9,13,60-62]$. Yeastexpressed GrB-TGF $\alpha$ (GrB-T) and GrB-scFv(FRP5) (GrB-5) proteins were bifunctional, cleaving synthetic and natural GrB substrates, and displaying strongly enhanced binding to cells carrying the respective EGFR or ErbB2 target receptors [23]. Following cell binding and receptor-mediated uptake, the chimeric molecules were rapidly internalized, but at the concentrations applied did not induce target cell death. Instead, GrB-T and GrB-5 remained trapped in intracellular vesicles, unable to gain access to cytosolic GrB substrates. Nevertheless, this problem was resolved by addition of an endosomolytic reagent such as chloroquine, now resulting in efficient release of the fusion proteins from endosomal vesicles and targeted cytotoxicity (Figure 2). Chloroquine accumulates in acidic compartments such as late endosomes and lysosomes, where it interferes with the $\mathrm{pH}$ equilibrium, finally leading to osmotic rupture of the vesicles [63]. Hence, retargeting of GrB to ErbB2 or EGFR must have resulted in routing to an acidic environment sensitive to chloroquine, as expected upon uptake of the fusion proteins via classical receptor-mediated endocytosis, but not typical for wildtype GrB. This was confirmed by the inability of chloroquine to release unfused GrB from intracellular vesicles upon uptake via natural GrB internalization mechanisms [49]. In the presence of chloroquine concentrations of 50 to $100 \mu \mathrm{M}, \mathrm{GrB}-5$ and GrB-T were able to specifically kill target cells with $\mathrm{IC}_{50}$ values measured after 14 hours of treatment in the picomolar to nanomolar range, whereas non-target cells were not affected at considerably higher concentrations [23,38] (Table 1). Cytotoxic activity was accompanied by clear signs of apoptosis such as chromatin condensation, membrane blebbing, formation of apoptotic bodies and activation of endogenous initiator and effector caspases. 
Figure 2. Cell killing activity and selectivity of an ErbB2-specific GrB - antibody fusion protein. ErbB2-expressing Renca-lacZ/ErbB2 (left panel) and ErbB2-negative Renca-lacZ renal carcinoma cells (right panel) were incubated for $14 \mathrm{~h}$ with the indicated concentrations of recombinant GrB-scFv(FRP5) (GrB-5) fusion protein in the presence of $50 \mu \mathrm{M}$ chloroquine. The relative number of viable cells in comparison to controls only treated with chloroquine was determined in cell viability assays as described [23]. For Renca-lacZ/ErbB2 target cells an $\mathrm{IC}_{50}$ value of $0.29 \mathrm{nM}(20 \mathrm{ng} / \mathrm{mL})$ was determined.
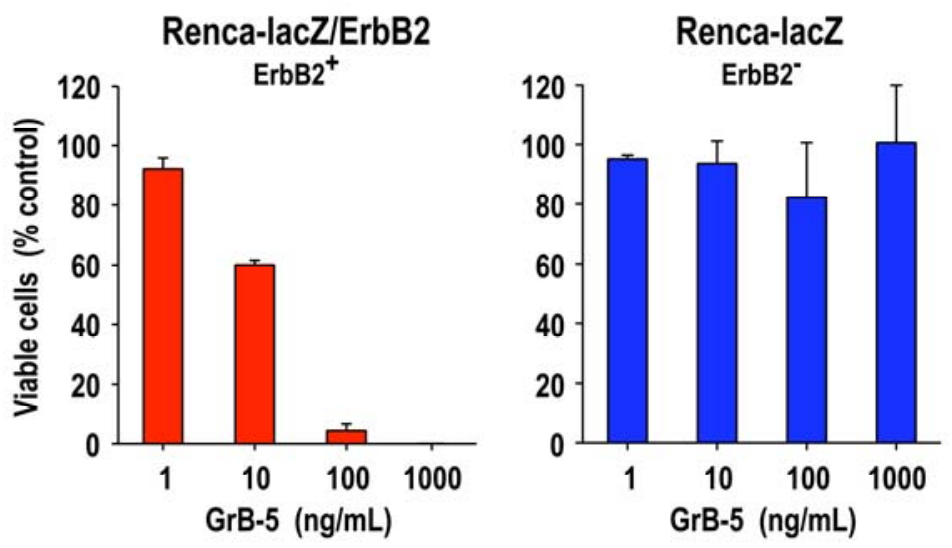

Table 1. Specificity and cytotoxicity of GrB fusion proteins and recombinant toxins.

\begin{tabular}{|c|c|c|c|c|}
\hline & & \multicolumn{3}{|c|}{ Tumor cell line } \\
\hline Reagent $^{a}$ & Specificity & $\begin{array}{c}\text { MDA-MB468 } \\
\text { EGFR }^{+}, \text {ErbB2 }^{-}\end{array}$ & $\begin{array}{c}\mathrm{A} 431^{\mathrm{b}} \\
\text { EGFR }^{+}, \text {ErbB2 }^{+}\end{array}$ & $\begin{array}{c}\text { Renca-lacZ/ErbB2 } \\
\text { EGFR }^{-}, \text {ErbB2 }^{+}\end{array}$ \\
\hline GrB-5 & ErbB2/HER2 & no killing at $14.5 \mathrm{nM}$ & $5.8 \mathrm{nM}$ & $0.29 \mathrm{nM}$ \\
\hline 5-ETA & ErbB2/HER2 & no killing at $15 \mathrm{nM}$ & $0.5 \mathrm{nM}$ & $0.09 \mathrm{nM}$ \\
\hline GrB-T & EGFR & $0.25 \mathrm{nM}$ & $3.5 \mathrm{nM}$ & no killing at $25 \mathrm{nM}$ \\
\hline T-ETA & EGFR & $0.06 \mathrm{nM}$ & $0.02 \mathrm{nM}$ & n.d. $^{\mathrm{c}}$ \\
\hline
\end{tabular}

${ }^{\mathrm{a}} \mathrm{IC}_{50}$ values for granzyme B fusion proteins GrB-scFv(FRP5) (GrB-5) and GrB-TGF $\alpha$ (GrB-T) were determined in cell viability assays upon treatment of cells with recombinant proteins for 14 hours in the presence of chloroquine as described [23,38]. $\mathrm{IC}_{50}$ values for Pseudomonas exotoxin A fusion proteins scFv(FRP5)-ETA (5-ETA) and TGF $\alpha$-ETA (T-ETA) were determined in cell viability assays upon treatment of cells with recombinant proteins for 40 hours as described $[61,62,64]$. MDA-MB468 and MDA-MB453 are established human breast carcinoma cells. Renca-lacZ/ErbB2 cells are murine renal carcinoma cells stably expressing human ErbB2 [64]. ${ }^{\mathrm{b}}$ Reduced sensitivity of human A431 squamous cell carcinoma cells to GrB fusion proteins was attributed to endogenous expression of GrB-specific serine protease inhibitor serpin P9 (PI-9) [23]. ${ }^{\mathrm{c}}$ n.d., not determined.

Similar to a Lewis Y-specific GrB immunoconjugate [51], cell killing by GrB-T and GrB-5 fusion proteins was 3-4 times less effective than that by Pseudomonas exotoxin A fusion proteins which employ the same cell targeting domains (Table 1). However, while the bacterial toxins required incubation times of at least $40 \mathrm{~h}$ for maximum in vitro cell killing, high cytotoxic activity of the $\mathrm{GrB}$ fusion proteins was already found after $14 \mathrm{~h}$ of treatment, and apoptotic morphology of target cells was observed as early as 2 hours after addition of chimeric GrB molecules, following kinetics similar to the $\mathrm{GrB}$ /perforin system [23]. Furthermore, target cells were killed even in the presence of the pan-caspase inhibitor zVAD-fmk, albeit to a lesser extent. This ability of GrB fusion proteins to also activate caspase-independent cell death pathways, possibly through cleavage of Bid or ICAD [43,44], can be relevant for elimination of tumor cells with a block in caspase-dependent apoptosis. 
For GrB fusion proteins targeting surface antigens other than growth factor receptors, selective cytotoxicity was obtained without the need for an endosome escape activity [22,50,51,53]. Nevertheless, in such cases 10 to 300 times higher protein concentrations and/or extended treatment times were required for half-maximal killing activity in vitro. Interestingly, also GrB-T displayed cell killing in the absence of chloroquine. However, to achieve a measurable effect, high protein concentrations $(\geq 12.5 \mathrm{nM})$ and incubation for $48 \mathrm{~h}$ were required [38]. These findings suggest that the type of target receptor determines uptake and intracellular routing of chimeric GrB molecules, and kinetics and efficiency of their access to the cytosol.

\section{Opportunities and Challenges for Further Development of Targeted Granzyme B}

\subsection{Target Cell Specificity of Granzyme B Fusion Proteins}

So far experience with chimeric GrB fusion proteins in in vivo models is limited. While remaining difficulties to scale up protein production to levels required for treatment of larger cohorts of experimental animals may be overcome by utilizing optimized expression systems in yeast, insect and mammalian cells $[24,58,65]$, also intrinsic features of GrB need to be addressed that may adversely affect availability of $\mathrm{GrB}$ fusions at the tumor site. With a calculated $\mathrm{pI}$ around $10, \mathrm{GrB}$ is a highly basic protein with a positively charged surface. This enables binding to glucosaminoglycans and other negatively charged structures on the surface of different cell types [66-68]. While natural GrB is released in complex with the chondroitin sulfate proteoglycan serglycin that shields its positively charged surface $[69,70]$, the therapeutic applicability of recombinant GrB derivatives may be limited by promiscuous binding of uncomplexed $\mathrm{GrB}$ to cell surface proteoglycans via electrostatic interactions $[66,67,71]$. This, in turn, could limit the amount of protein available for specific tumor cell killing. Bird et al. identified two cationic sequence loops RKAKRTR (residues 116 to 122) and KKTMKR (residues 241 to 246) within GrB that electrostatically interact with heparan-sulfatecontaining molecules [66] (Figure 3a,b). Mutation of these sequences resulted in diminished cell binding and suppression of subsequent endocytosis, but disturbed perforin-assisted cytotoxicity. More recently, also residues K133 and K137 were implicated in non-selective cell binding of GrB [68].

Following an approach similar to that of Bird et al., we mutated the two cationic heparin-binding motifs responsible for non-selective electrostatic interactions of $\mathrm{GrB}$ with cell surface structures to generate a surface charge-modified GrB variant termed GrBcs. Yeast-expressed GrBcs retained the enzymatic activity of wildtype $\mathrm{GrB}$, but displayed markedly reduced intrinsic cell binding [38]. When fused to TGF $\alpha$ for tumor targeting, the resulting GrBcs-T molecule showed enzymatic activity in cell-free assays that was indistinguishable from that of unmodified GrB-T. However, binding of GrBcs-T to EGFR-negative cells was abolished (Figure 3c), while binding to EGFR-positive cells and target-specific cell killing were retained (Figure 3d). When tested in mixed cultures of EGFR-negative and EGFR-positive cells, GrBcs-T in contrast to GrB-T was not sequestrated by binding to cells devoid of target antigen. This greatly increased the availability of the modified GrBcs-T molecule for specific target cell killing [38]. Hence, systemically applied chimeric molecules that employ surface charge-modified GrB will be less likely than similar proteins based on wildtype GrB to be trapped by binding to non-target tissues before reaching the tumor site. 
Figure 3. (a) Electrostatic surface potential of granzyme B. Positively charged areas are represented in blue. Residues mutated in the charge-modified derivative GrBcs are indicated. The model is based on the crystal structure of human GrB (1FQ3) [72] (generated with DeepView Swiss-PdbViewer; spdbv.vital-it.ch). (b) Positively charged residues within $\mathrm{GrB}$ (indicated in blue) were replaced by alanine residues (indicated in red) to obtain the charge-modified derivative GrBcs [38,66]. (c) Differential cell binding of targeted GrB proteins consisting of TGF $\alpha$ fused to the C-terminus of wildtype GrB (GrB-T) or charge-modified GrBcs (GrBcs-T). Unlabeled EGFR-negative MDA-MB453 breast carcinoma cells (blue) were mixed with fluorescently labeled EGFR-positive MDAMB468 breast carcinoma cells (red) at a ratio of 1:1 or 10:1 prior to incubation with GrB-T (left panels) or GrBcs-T fusion proteins (right panels). Cell binding was analyzed by flow cytometry with Alexa Fluor 647-conjugated GrB-specific antibody as described [38]. (d) Cytotoxic activity of surface charge-modified GrBcs-T. EGFR-positive MDA-MB468 (upper panel) and EGFR-negative MDA-MB453 cells (lower panel) were treated with the indicated concentrations of purified GrB-T (blue circles) or GrBcs-T protein (red circles) for 14 hours in the presence of $50 \mu \mathrm{M}$ chloroquine. The relative number of viable cells in comparison to controls treated only with chloroquine was determined in cell viability assays as described [38].

a

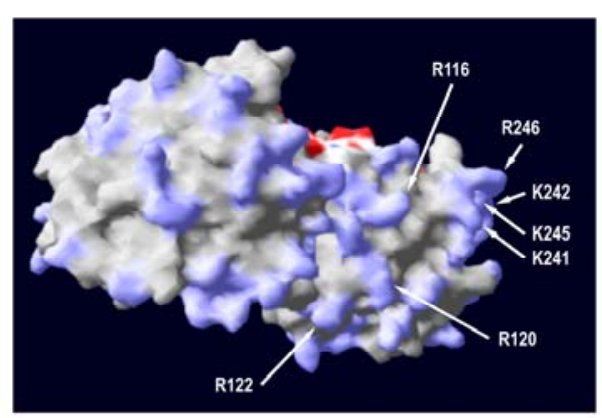

C

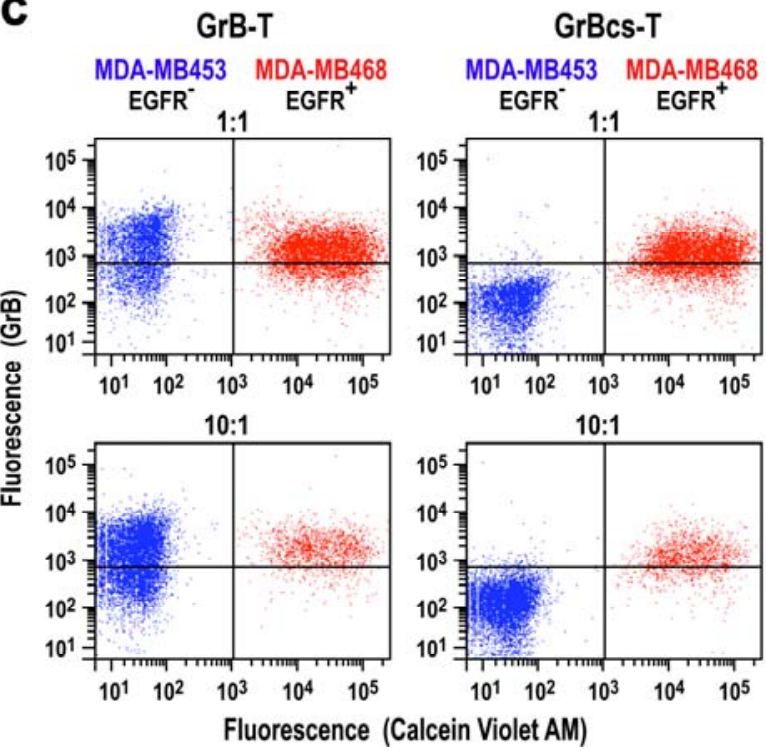

b

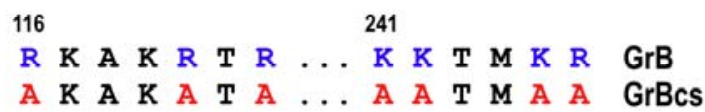

d

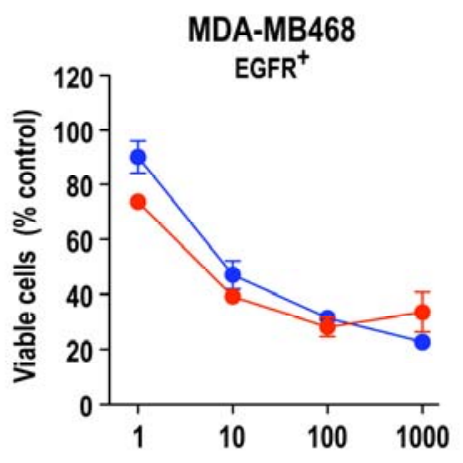

MDA-MB453

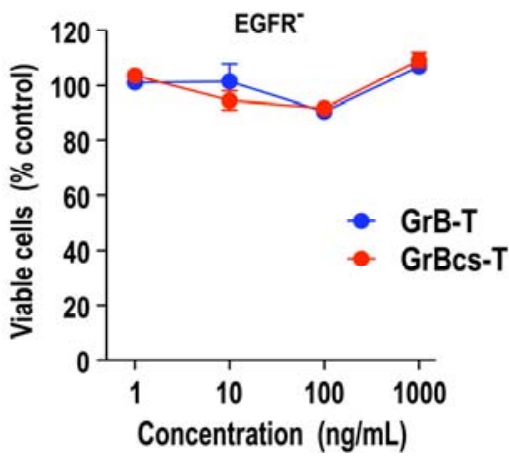




\subsection{Extracellular Activity of Granzyme B}

In addition to its apoptosis-inducing activity within target cells, the serine protease $\mathrm{GrB}$ can also process components of the extracellular matrix [39,73], which may be important for tissue remodeling in the course of an ongoing immune reaction. However, excessive extracellular activity of GrB has been linked to pathophysiological conditions such as rheumatoid arthritis [74,75], cardiovascular [76-78] and neurodegenerative diseases [79], and may complicate application of large doses of recombinant GrB proteins for therapeutic purposes. Like intrinsic cell binding, interaction of GrB with extracellular substrates has been linked to the high positive surface charge of the molecule [80]. To investigate potential differences in the extracellular activities of wildtype $\mathrm{GrB}$ and GrBcs derivatives, we employed human HeLa cervix carcinoma cells as a model. These cells undergo morphological changes upon degradation of their extracellular matrix by $\mathrm{GrB}$ [49], but are not sensitive to the apoptosisinducing effects of EGFR-specific GrB-T or GrBcs-T proteins in the absence of chloroquine. While exposure to GrB-T or untargeted GrB resulted in a concentration-dependent loss of adherent cells, GrBcs-T and GrBcs induced only minimal cell detachment [38]. This confirms that electrostatic interactions play an important role for the extracellular proteolytic activity of GrB and GrB fusion proteins, which can be controlled by surface charge-modification as in the case of unspecific cell binding.

\subsection{Granzyme B Resistance of Tumor Cells}

The cellular serine protease inhibitor (serpin) PI-9 is an effective and highly specific physiological inhibitor of GrB [81,82]. PI-9 is abundantly expressed in CTL and NK cells to protect them from misdirected endogenous GrB. In addition, significant PI-9 levels have been found in B cells [81], monocytes [83], dendritic cells [84,85], and other bystander cell types that need to be shielded from GrB-mediated killing during an ongoing immune response. PI-9 is also present in normal human plasma, but at the given concentrations, it does not efficiently inhibit GrB activity [51]. This suggests that systemic application of targeted GrB fusion proteins may not be drastically affected by PI-9 circulating in the blood. More importantly, PI-9 expression has been found in tumor cells, where it constitutes a potential resistance mechanism to escape elimination by cytotoxic lymphocytes $[86,87]$. While PI-9 does not provide complete protection of tumor cells, it reduces their sensitivity for GrBmediated cell death. Consistent with this, a strong correlation between PI-9 expression in the tumor and disease progression has been shown for different cancer types [88-90]. It is conceivable that this variable expression of PI-9 in tumor cells could significantly affect susceptibility to targeted GrB fusion proteins, as already evident from in vitro assays, where sensitivity for EGFR- and ErbB2specific GrB-T and GrB-5 proteins was approximately 20 times lower for cancer cells with PI-9 expression despite high levels of the target antigens (see Table 1). Using a computational approach, Losasso et al. recently identified residues of human GrB important for interaction with PI-9 [91]. Employing molecular dynamic simulations, the mutations R28K, R201A and R201K within GrB were found to significantly destabilize GrB-PI-9 interaction, and the modified GrB variants retained enzymatic activity in the presence of PI-9. From this study, in particular the GrB mutant R201K emerged as a promising candidate suitable for the generation of novel, PI-9-resistant GrB fusion proteins. Also combination of $\mathrm{GrB}$ fusion proteins with reagents counteracting anti-apoptotic mechanisms in tumor 
cells may enhance targeted cell killing, as recently observed for GrB combined with the Bcl-2 inhibitor ABT-737 [92].

\subsection{Intracellular Routing and Cytosolic Delivery of Granzyme B}

Perhaps the biggest hurdle for targeted cytotoxic proteins that act inside cells is effective cytosolic delivery of the toxic payload. In general, for such chimeric proteins to have the desired antitumoral activity, they must bind specifically to a tumor-associated cell surface antigen, followed by internalization into target cells, and translocation of the whole molecule or an enzymatically active fragment to the cytosol for induction of cell death. Bacterial toxins such as Pseudomonas exotoxin A or diphtheria toxin (DT) have endogenous endosome escape activity, which can be readily employed for cytosolic delivery of recombinant ETA- and DT-based toxins [7]. While certain GrB fusion proteins are obviously able to reach the cytosol to some degree on their own [24], this does not appear to be as efficient as desirable, and GrB fusion proteins targeted to EGFR or ErbB2 were shown to be trapped in endosomal vesicles after receptor-mediated uptake. They require an exogenously provided endosomolytic activity like chloroquine to induce cell death at low concentrations [23,38]. Chloroquine has already been employed in animals models as an endosome release agent in conjunction with other therapeutic molecules [93], and is being used since many years for the treatment of malaria and other diseases in humans [94]. Nevertheless, high doses and long term use of chloroquine can be associated with toxicity. Furthermore, the development of combined treatment regimens may be complicated by the different pharmacokinetics of a low molecular weight drug such as chloroquine and much larger chimeric GrB fusion proteins. In principle, integration of the translocation domains of ETA or DT into GrB fusion proteins could be useful to enhance cytosolic delivery [95-97]. Nevertheless, this compromises the aim to develop fully humanized immunotoxinlike molecules. Alternatively, functional domains from members of the Bcl-2 protein family may be employed, some of which exhibit a high degree of structural similarity with the DT translocation domain and have membrane-inserting capabilities [98]. In addition, perforin-derived peptides or fulllength perforin may be able to cooperate with targeted $\mathrm{GrB}$, if the size restriction of perforin pores is not being exceeded $[50,68]$.

\subsection{Activity of Granzyme Fusion Proteins against Resting Cancer Cells}

While the majority of malignant cells within a tumor may grow rapidly, some of the cells including cancer stem or cancer initiating cells can be quiescent and in a resting state (G0 phase of the cell cycle). Cancer stem cells are characterized by self-renewal and multi-lineage differentiation capacity, but also by an intrinsic resistance to chemotherapeutics [99]. In contrast to most cytotoxic drugs, targeted protein toxins and apoptosis inducing molecules such as GrB do not rely on interference with DNA replication and cell division for their effects. Nevertheless, also apoptosis sensitivity is reduced in resting tumor cells, which may impact on the efficacy of immunotoxin-like molecules. So far, this aspect has not been addressed in the context of targeted GrB fusion proteins. In pilot experiments, we investigated sensitivity of human breast carcinoma cells for EGFR-specific GrBcs-T and ErbB2specific GrB-5 fusion proteins depending on whether or not they were actively dividing. Resting EGFR-expressing MDA-MB468 cells were still killed by GrBcs-T, albeit requiring significantly 
higher protein concentrations than dividing cells (Figure 4a, left panel; see Figure 3d for comparison). In contrast, GrB-5 had only minimal activity against resting ErbB2-expressing MDA-MB453 cells, but cytotoxicity was rapidly restored upon addition of serum to induce proliferation (Figure 4b, left panels). These results suggest that activity of GrB fusion proteins against resting cells may be affected by the type of the cell binding domain, and the activation state and internalization rate of the target receptor. While GrBcs-T contains functional TGF $\alpha$ and can activate EGFR for signaling and internalization in the absence of growth factors from serum, this is different for monovalent GrB-5, which does not induce ErbB2 dimerization, activation and internalization on its own (Figure 4, right panels). Further work and in-depth analysis will be required to elucidate killing of resting cells by GrB fusion proteins in detail, and extend these findings to molecules targeting other surface antigens.

Figure 4. Cytotoxic activity of targeted GrB proteins against resting cells. (a) EGFRpositive MDA-MB468 breast carcinoma cells were starved for $4 \mathrm{~h}$ by incubation in low serum $(0.5 \%$ FCS $)$, before treatment for $24 \mathrm{~h}$ with $1 \mu \mathrm{g} / \mathrm{mL}(25 \mathrm{nM})$ of EGFR-specific GrBcs-T protein in the presence of $50 \mu \mathrm{M}$ chloroquine in medium also containing $0.5 \%$ FCS. (b) ErbB2-positive MDA-MB453 breast carcinoma cells were starved for $4 \mathrm{~h}$ by incubation in low serum (0.5\% FCS), before treatment for $24 \mathrm{~h}$ with $1 \mu \mathrm{g} / \mathrm{mL}$ of ErbB2specific GrB-5 protein in the presence of $50 \mu \mathrm{M}$ chloroquine in medium also containing $0.5 \%$ FCS (left panel). Alternatively, cells were treated for $4 \mathrm{~h}$ with $1 \mu \mathrm{g} / \mathrm{mL}$ of GrB-5 protein in medium containing $0.5 \%$ FCS in the absence of chloroquine, washed, and incubated for another $20 \mathrm{~h}$ with complete medium (10\% FCS) (middle panel). In (a) and (b) control cells were treated with untargeted GrBcs protein. The relative number of viable cells in comparison to controls treated without GrB proteins was determined in cell viability assays as described [38]. The activation state of EGFR and ErbB2 upon binding of GrB-T and GrB-5 proteins is schematically shown on the right.
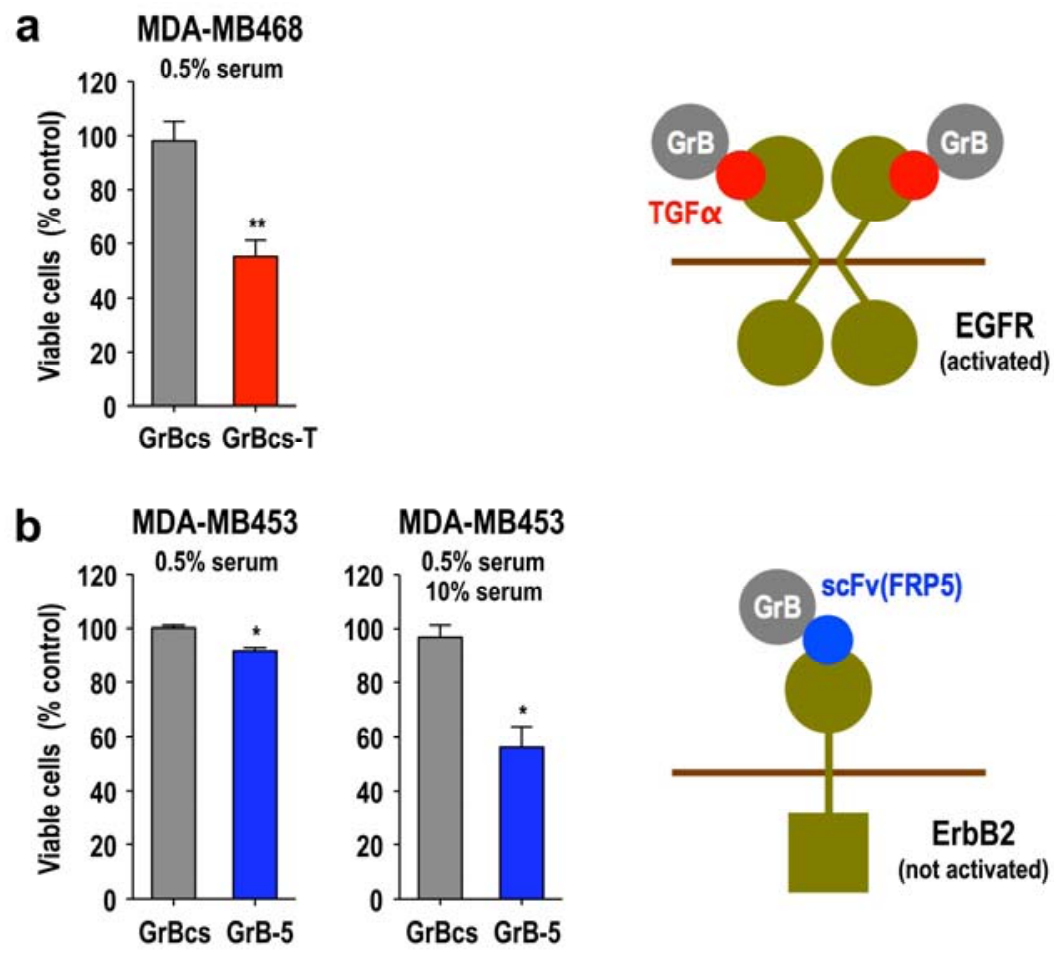


\subsection{Local Delivery of Targeted Granzyme B by Genetically Modified Lymphocytes}

T-lymphocytes and NK cells have the intrinsic potential to extravasate and to reach their targets in almost all body tissues. These cells are therefore ideally suited to invade tumors in vivo. Utilizing genetically modified immune cells for in vivo production of targeted GrB upon adoptive transfer could bypass the necessity for large-scale production of recombinant GrB fusion proteins, and may enhance availability of the therapeutic proteins in the tumor vicinity. Previously, Zhao et al. designed an ErbB2-specific GrB fusion protein for expression in $\mathrm{T}$ cells based on the structure of Pseudomonas exotoxin A. This molecule carried an $\mathrm{N}$-terminal scFv antibody domain for cell recognition, fused via the ETA translocation domain to $\mathrm{GrB}$ as a C-terminal domain [95]. Established Jurkat $\mathrm{T}$ cells that expressed the targeted GrB displayed activity against ErbB2-expressing tumor cells in vitro and in vivo, which was attributed to the activity of the fusion protein. Unfortunately, the study did not address the question how a correctly processed and enzymatically active GrB fragment could be generated based on the chosen protein design, and whether a fusion protein carrying $\mathrm{GrB}$ at the N-terminus may have been more effective. Possibly, activation of GrB occurred by partial proteolytic degradation upon uptake into target cells. To investigate feasibility and consequences of expression of chimeric GrB fusion proteins reflecting the structure of current targeted $\mathrm{GrB}$ molecules, we genetically modified human NK cells by transduction with lentiviral vectors (Figure 5). NK cells possess all pathways required for processing, packaging, and triggered release of endogenous wildtype GrB, and may be readily employed for ectopic expression of retargeted $\mathrm{GrB}$.

Figure 5. Intracellular localization of a GrB fusion protein expressed in natural killer cells. Established human NKL cells [100] were transduced with a lentiviral vector encoding human pre-pro-GrB genetically fused to enhanced green fluorescent protein (EGFP) (left), or a control vector encoding unfused EGFP (right). Intracellular localization of GrB-EGFP and EGFP proteins was analyzed by confocal laser scanning microscopy (upper panels). Bright field microscopic images of the same cells are shown in bottom panels.

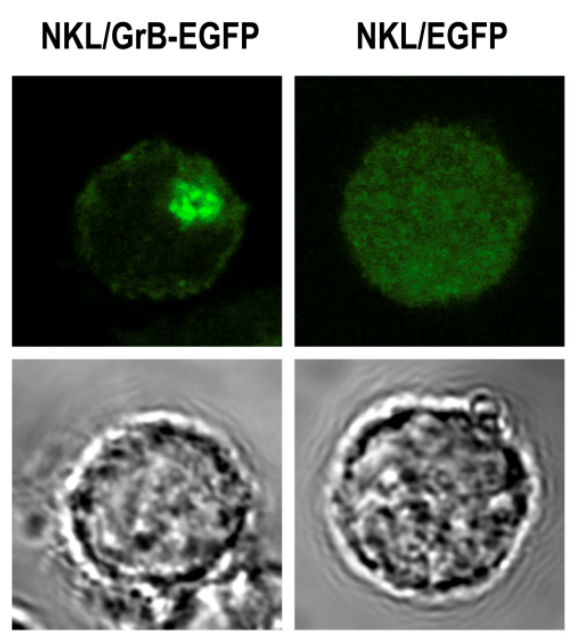

For initial analysis, we chose a model protein that carried full-length human GrB at the N-terminus, fused to a C-terminal enhanced green fluorescent protein (EGFP) domain as a marker. The GrB-EGFP protein was readily expressed by gene-modified NK cells, and routed to vesicular structures consistent 
with cytotoxic granules. Likewise, GrB-5 and GrB-T molecules were successfully expressed, and shown to be released in correctly processed and enzymatically active form together with endogenous granzymes and perforin upon triggered activation of the respective NK cells [101]. Combined expression of targeted GrB and tumor-specific chimeric antigen receptors in NK cells may now allow selective enrichment of such cells within a tumor [7,102], and increased antitumoral activity through cooperation of GrB fusion proteins with natural cytotoxicity mechanisms.

\section{Conclusions}

Targeted GrB fusion proteins hold promise as tools for directed cancer therapy. They structurally and functionally reflect recombinant toxins, but employ an effector domain of human origin expected to result in low or no immunogenicity. GrB is an enzyme, enabling amplification of its cell-death inducing activity through cleavage and activation of cellular caspases, and induction of caspaseindependent apoptosis pathways. Targeted GrB fusion proteins are relatively novel molecules, investigated for less than a decade. During this time, suitable protein designs have been developed based on the structure and activation mechanism of the parental molecule, which allows successful combination of $\mathrm{GrB}$ with heterologous cell binding domains. Importantly, the prototypic fusion proteins described so far fulfill the basic requirement of specificity with respect to cytotoxic activity against tumor cells in vitro and in animal models. Significant progress has been made towards the development of optimized GrB derivatives with enhanced bioavailability and antitumoral activity. Recent advances in understanding and circumventing intrinsic cell binding of GrB and susceptibility of the enzyme to inhibition by serpins will now allow the rational design of next-generation GrB derivatives that avoid sequestration by binding to non-target tissues, limit off-target effects, and overcome resistance mechanisms in tumor cells. While endosomal entrapment of targeted GrB remains a critical issue, protein delivery across the plasma membrane is a very general problem and under active investigation from many sides. Ongoing approaches to convert GrB into molecules of true therapeutic value will also continue to benefit from advances in the field of apoptosis research, providing details of this enzyme's mode of action, and its multiple functions in normal physiology and various disease states.

\section{Acknowledgments}

The authors thank Thorsten Geyer and Barbara Uherek for technical assistance, Benjamin Dälken and Hayat Bähr-Mahmud for helpful discussions, and Torsten Tonn for providing lentiviral vector encoding GrB-EGFP fusion protein. This work was supported by Deutsche Forschungsgemeinschaft (DFG) grant WE 2589/2-1, DFG Graduiertenkolleg GRK1172, LOEWE Center for Cell and Gene Therapy Frankfurt (all to W.S.W.), and institutional funds of the Georg-Speyer-Haus. The GeorgSpeyer-Haus is funded jointly by the German Federal Ministry of Health (BMG) and the Ministry of Higher Education, Research and the Arts of the State of Hessen (HMWK). The LOEWE Center for Cell and Gene Therapy Frankfurt is funded by HMWK, reference number: III L 4- 518/17.004 (2010). 


\section{References and Notes}

1. Maloney, D.G. Immunotherapy for non-Hodgkin's lymphoma: Monoclonal antibodies and vaccines. J. Clin. Oncol. 2005, 23, 6421-6428.

2. Groner, B.; Hartmann, C.; Wels, W. Therapeutic antibodies. Curr. Mol. Med. 2004, 4, 539-547.

3. Hynes, N.E.; Lane, H.A. ERBB receptors and cancer: The complexity of targeted inhibitors. Nat. Rev. Cancer 2005, 5, 341-354.

4. Lan, K.H.; Lu, C.H.; Yu, D. Mechanisms of trastuzumab resistance and their clinical implications. Ann. NY Acad. Sci. 2005, 1059, 70-75.

5. Nahta, R.; Esteva, F.J. HER2 therapy: molecular mechanisms of trastuzumab resistance. Breast Cancer Res. 2006, 8, 215.

6. Weldon, J.E.; Pastan, I. A guide to taming a toxin--recombinant immunotoxins constructed from Pseudomonas exotoxin A for the treatment of cancer. FEBS J. 2011, 278, 4683-4700.

7. Wels, W.; Biburger, M.; Müller, T.; Dälken, B.; Giesübel, U.; Tonn, T.; Uherek, C. Recombinant immunotoxins and retargeted killer cells: employing engineered antibody fragments for tumorspecific targeting of cytotoxic effectors. Cancer Immunol. Immunother. 2004, 53, 217-226.

8. Pastan, I.; Hassan, R.; Fitzgerald, D.J.; Kreitman, R.J. Immunotoxin therapy of cancer. Nat. Rev. Cancer 2006, 6, 559-565.

9. von Minckwitz, G.; Harder, S.; Hovelmann, S.; Jäger, E.; Al-Batran, S.E.; Loibl, S.; Atmaca, A.; Cimpoiasu, C.; Neumann, A.; Abera, A.; et al. Phase I clinical study of the recombinant antibody toxin scFv(FRP5)-ETA specific for the ErbB2/HER2 receptor in patients with advanced solid malignomas. Breast Cancer Res. 2005, 7, R617-R626.

10. Kreitman, R.J.; Pastan, I. Antibody fusion proteins: Anti-CD22 recombinant immunotoxin moxetumomab pasudotox. Clin. Cancer Res. 2011, 17, 6398-6405.

11. Kelly, R.J.; Sharon, E.; Pastan, I.; Hassan, R. Mesothelin-targeted agents in clinical trials and in preclinical development. Mol. Cancer Ther. 2012, 11, 517-525.

12. Pai, L.H.; Wittes, R.; Setser, A.; Willingham, M.C.; Pastan, I. Treatment of advanced solid tumors with immunotoxin LMB-1: An antibody linked to Pseudomonas exotoxin. Nat. Med. 1996, 2, 350-353.

13. Azemar, M.; Djahansouzi, S.; Jäger, E.; Solbach, C.; Schmidt, M.; Maurer, A.B.; Mross, K.; Unger, C.; von Minckwitz, G.; Dall, P.; et al. Regression of cutaneous tumor lesions in patients intratumorally injected with a recombinant single-chain antibody-toxin targeted to ErbB2/HER2. Breast Cancer Res. Treat. 2003, 82, 155-164.

14. Keppler-Hafkemeyer, A.; Kreitman, R.J.; Pastan, I. Apoptosis induced by immunotoxins used in the treatment of hematologic malignancies. Int. J. Cancer 2000, 87, 86-94.

15. Schmidt, M.; McWatters, A.; White, R.A.; Groner, B.; Wels, W.; Fan, Z.; Bast, R.C., Jr. Synergistic interaction between an anti-p185HER-2 pseudomonas exotoxin fusion protein [scFv(FRP5)-ETA] and ionizing radiation for inhibiting growth of ovarian cancer cells that overexpress HER-2. Gynecol. Oncol. 2001, 80, 145-155.

16. Weidle, U.H.; Georges, G.; Brinkmann, U. Fully human targeted cytotoxic fusion proteins: New anticancer agents on the horizon. Cancer Genomics Proteomics 2012, 9, 119-133. 
17. Gerspach, J.; Wajant, H.; Pfizenmaier, K. Death ligands designed to kill: development and application of targeted cancer therapeutics based on proapoptotic TNF family ligands. Results Probl. Cell Differ. 2009, 49, 241-273.

18. Antignani, A.; Youle, R.J. A chimeric protein induces tumor cell apoptosis by delivering the human Bcl-2 family BH3-only protein Bad. Biochemistry 2005, 44, 4074-4082.

19. Lorberboum-Galski, H. Human toxin-based recombinant immunotoxins/chimeric proteins as a drug delivery system for targeted treatment of human diseases. Expert Opin. Drug Deliv. 2011, $8,605-621$.

20. Hanahan, D.; Weinberg, R.A. Hallmarks of cancer: the next generation. Cell 2011, 144, 646-674.

21. Mahmud, H.; Dälken, B.; Wels, W.S. Induction of programmed cell death in ErbB2/HER2expressing cancer cells by targeted delivery of apoptosis-inducing factor. Mol. Cancer Ther. 2009, 8, 1526-1535.

22. Liu, Y.; Cheung, L.H.; Thorpe, P.; Rosenblum, M.G. Mechanistic studies of a novel human fusion toxin composed of vascular endothelial growth factor (VEGF)121 and the serine protease granzyme B: Directed apoptotic events in vascular endothelial cells. Mol. Cancer Ther. 2003, 2, 949-959.

23. Dälken, B.; Giesübel, U.; Knauer, S.K.; Wels, W.S. Targeted induction of apoptosis by chimeric granzyme B fusion proteins carrying antibody and growth factor domains for cell recognition. Cell Death Differ. 2006, 13, 576-585.

24. Rosenblum, M.G.; Barth, S. Development of novel, highly cytotoxic fusion constructs containing granzyme B: unique mechanisms and functions. Curr. Pharm. Des. 2009, 15, 2676-2692.

25. Kurschus, F.C.; Jenne, D.E. Delivery and therapeutic potential of human granzyme B. Immunol. Rev. 2010, 235, 159-171.

26. Cullen, S.P.; Brunet, M.; Martin, S.J. Granzymes in cancer and immunity. Cell Death Differ. 2010, 17, 616-623.

27. Pham, C.T.; Ley, T.J. Dipeptidyl peptidase I is required for the processing and activation of granzymes A and B in vivo. Proc. Natl. Acad. Sci. USA 1999, 96, 8627-8632.

28. Chowdhury, D.; Lieberman, J. Death by a thousand cuts: Granzyme pathways of programmed cell death. Annu. Rev. Immunol. 2008, 26, 389-420.

29. Bromley, S.K.; Burack, W.R.; Johnson, K.G.; Somersalo, K.; Sims, T.N.; Sumen, C.; Davis, M.M.; Shaw, A.S.; Allen, P.M.; Dustin, M.L. The immunological synapse. Annu. Rev. Immunol. 2001, 19, 375-396.

30. Huse, M.; Quann, E.J.; Davis, M.M. Shouts, whispers and the kiss of death: Directional secretion in T cells. Nat. Immunol. 2008, 9, 1105-1111.

31. Afonina, I.S.; Cullen, S.P.; Martin, S.J. Cytotoxic and non-cytotoxic roles of the CTL/NK protease granzyme B. Immunol. Rev. 2010, 235, 105-116.

32. Baran, K.; Dunstone, M.; Chia, J.; Ciccone, A.; Browne, K.A.; Clarke, C.J.; Lukoyanova, N.; Saibil, H.; Whisstock, J.C.; Voskoboinik, I.; et al. The molecular basis for perforin oligomerization and transmembrane pore assembly. Immunity 2009, 30, 684-695.

33. Law, R.H.; Lukoyanova, N.; Voskoboinik, I.; Caradoc-Davies, T.T.; Baran, K.; Dunstone, M.A.; D'Angelo, M.E.; Orlova, E.V.; Coulibaly, F.; Verschoor, S.; et al. The structural basis for membrane binding and pore formation by lymphocyte perforin. Nature 2010, 468, 447-451. 
34. Thiery, J.; Keefe, D.; Saffarian, S.; Martinvalet, D.; Walch, M.; Boucrot, E.; Kirchhausen, T.; Lieberman, J. Perforin activates clathrin- and dynamin-dependent endocytosis, which is required for plasma membrane repair and delivery of granzyme B for granzyme-mediated apoptosis. Blood 2010, 115, 1582-1593.

35. Thiery, J.; Keefe, D.; Boulant, S.; Boucrot, E.; Walch, M.; Martinvalet, D.; Goping, I.S.; Bleackley, R.C.; Kirchhausen, T.; Lieberman, J. Perforin pores in the endosomal membrane trigger the release of endocytosed granzyme B into the cytosol of target cells. Nat. Immunol. 2011, 12, 770-777.

36. Gross, C.; Koelch, W.; DeMaio, A.; Arispe, N.; Multhoff, G. Cell surface-bound heat shock protein 70 (Hsp70) mediates perforin-independent apoptosis by specific binding and uptake of granzyme B. J. Biol. Chem. 2003, 278, 41173-41181.

37. Gehrmann, M.; Stangl, S.; Kirschner, A.; Foulds, G.A.; Sievert, W.; Doss, B.T.; Walch, A.; Pockley, A.G.; Multhoff, G. Immunotherapeutic targeting of membrane Hsp70-expressing tumors using recombinant human granzyme B. PLoS One 2012, 7, e41341.

38. Jabulowsky, R.A.; Oberoi, P.; Bähr-Mahmud, H.; Dälken, B.; Wels, W.S. Surface chargemodification prevents sequestration and enhances tumor-cell specificity of a recombinant granzyme B-TGFalpha fusion protein. Bioconjug. Chem. 2012, 23, 1567-1576.

39. Boivin, W.A.; Cooper, D.M.; Hiebert, P.R.; Granville, D.J. Intracellular versus extracellular granzyme B in immunity and disease: challenging the dogma. Lab. Invest. 2009, 89, 1195-1220.

40. Thornberry, N.A.; Rano, T.A.; Peterson, E.P.; Rasper, D.M.; Timkey, T.; Garcia-Calvo, M.; Houtzager, V.M.; Nordstrom, P.A.; Roy, S.; Vaillancourt, J.P.; et al. A combinatorial approach defines specificities of members of the caspase family and granzyme B. Functional relationships established for key mediators of apoptosis. J. Biol. Chem. 1997, 272, 17907-17911.

41. Adrain, C.; Murphy, B.M.; Martin, S.J. Molecular ordering of the caspase activation cascade initiated by the cytotoxic T lymphocyte/natural killer (CTL/NK) protease granzyme B. J. Biol. Chem. 2005, 280, 4663-4673.

42. Barry, M.; Heibein, J.A.; Pinkoski, M.J.; Lee, S.F.; Moyer, R.W.; Green, D.R.; Bleackley, R.C. Granzyme B short-circuits the need for caspase 8 activity during granule-mediated cytotoxic T-lymphocyte killing by directly cleaving Bid. Mol. Cell. Biol. 2000, 20, 3781-3794.

43. Waterhouse, N.J.; Sedelies, K.A.; Browne, K.A.; Wowk, M.E.; Newbold, A.; Sutton, V.R.; Clarke, C.J.; Oliaro, J.; Lindemann, R.K.; Bird, P.I.; et al. A central role for Bid in granzyme Binduced apoptosis. J. Biol. Chem. 2005, 280, 4476-4482.

44. Thomas, D.A.; Du, C.; Xu, M.; Wang, X.; Ley, T.J. DFF45/ICAD can be directly processed by granzyme B during the induction of apoptosis. Immunity 2000, 12, 621-632.

45. Sharif-Askari, E.; Alam, A.; Rheaume, E.; Beresford, P.J.; Scotto, C.; Sharma, K.; Lee, D.; DeWolf, W.E.; Nuttall, M.E.; Lieberman, J.; et al. Direct cleavage of the human DNA fragmentation factor- 45 by granzyme $\mathrm{B}$ induces caspase-activated DNase release and DNA fragmentation. EMBO J. 2001, 20, 3101-3113.

46. Adrain, C.; Duriez, P.J.; Brumatti, G.; Delivani, P.; Martin, S.J. The cytotoxic lymphocyte protease, granzyme $\mathrm{B}$, targets the cytoskeleton and perturbs microtubule polymerization dynamics. J. Biol. Chem. 2006, 281, 8118-8125. 
47. Zhang, D.; Beresford, P.J.; Greenberg, A.H.; Lieberman, J. Granzymes A and B directly cleave lamins and disrupt the nuclear lamina during granule-mediated cytolysis. Proc. Natl. Acad. Sci. USA 2001, 98, 5746-5751.

48. Froelich, C.J.; Hanna, W.L.; Poirier, G.G.; Duriez, P.J.; D'Amours, D.; Salvesen, G.S.; Alnemri, E.S.; Earnshaw, W.C.; Shah, G.M. Granzyme B/perforin-mediated apoptosis of Jurkat cells results in cleavage of poly(ADP-ribose) polymerase to the $89-\mathrm{kDa}$ apoptotic fragment and less abundant 64-kDa fragment. Biochem. Biophys. Res. Commun. 1996, 227, 658-665.

49. Giesübel, U.; Dälken, B.; Mahmud, H.; Wels, W.S. Cell binding, internalization and cytotoxic activity of human granzyme B expressed in the yeast Pichia pastoris. Biochem. J. 2006, 394, $563-573$.

50. Liu, Y.; Cheung, L.H.; Hittelman, W.N.; Rosenblum, M.G. Targeted delivery of human pro-apoptotic enzymes to tumor cells: In vitro studies describing a novel class of recombinant highly cytotoxic agents. Mol. Cancer Ther. 2003, 2, 1341-1350.

51. Kurschus, F.C.; Kleinschmidt, M.; Fellows, E.; Dornmair, K.; Rudolph, R.; Lilie, H.; Jenne, D.E. Killing of target cells by redirected granzyme B in the absence of perforin. FEBS Lett. 2004, 562, 87-92.

52. Lorentsen, R.H.; Fynbo, C.H.; Thogersen, H.C.; Etzerodt, M.; Holtet, T.L. Expression, refolding, and purification of recombinant human granzyme B. Protein Expr. Purif. 2005, 39, 18-26.

53. Stahnke, B.; Thepen, T.; Stocker, M.; Rosinke, R.; Jost, E.; Fischer, R.; Tur, M.K.; Barth, S. Granzyme B-H22(scFv), a human immunotoxin targeting CD64 in acute myeloid leukemia of monocytic subtypes. Mol. Cancer Ther. 2008, 7, 2924-2932.

54. Gehrmann, M.; Doss, B.T.; Wagner, M.; Zettlitz, K.A.; Kontermann, R.E.; Foulds, G.; Pockley, A.G.; Multhoff, G. A novel expression and purification system for the production of enzymatic and biologically active human granzyme B. J. Immunol. Methods 2011, 371, 8-17.

55. Cereghino, J.L.; Cregg, J.M. Heterologous protein expression in the methylotrophic yeast Pichia pastoris. FEMS Microbiol. Rev. 2000, 24, 45-66.

56. Pham, C.T.; Thomas, D.A.; Mercer, J.D.; Ley, T.J. Production of fully active recombinant murine granzyme B in yeast. J. Biol. Chem. 1998, 273, 1629-1633.

57. Sun, J.; Bird, C.H.; Buzza, M.S.; McKee, K.E.; Whisstock, J.C.; Bird, P.I. Expression and purification of recombinant human granzyme B from Pichia pastoris. Biochem. Biophys. Res. Commun. 1999, 261, 251-255.

58. Dälken, B.; Jabulowsky, R.A.; Oberoi, P.; Benhar, I.; Wels, W.S. Maltose-binding protein enhances secretion of recombinant human granzyme B accompanied by in vivo processing of a precursor MBP fusion protein. PLoS One 2010, 5, e14404.

59. Liu, Y.; Zhang, W.; Niu, T.; Cheung, L.H.; Munshi, A.; Meyn, R.E.; Rosenblum, M.G. Targeted apoptosis activation with GrB/scFvMEL modulates melanoma growth, metastatic spread, chemosensitivity, and radiosensitivity. Neoplasia 2006, 8, 125-135.

60. Wels, W.; Harwerth, I.M.; Mueller, M.; Groner, B.; Hynes, N.E. Selective inhibition of tumor cell growth by a recombinant single-chain antibody-toxin specific for the erbB-2 receptor. Cancer Res. 1992, 52, 6310-6317. 
61. Wels, W.; Beerli, R.; Hellmann, P.; Schmidt, M.; Marte, B.M.; Kornilova, E.S.; Hekele, A.; Mendelsohn, J.; Groner, B.; Hynes, N.E. EGF receptor and p185erbB-2-specific single-chain antibody toxins differ in their cell-killing activity on tumor cells expressing both receptor proteins. Int. J. Cancer 1995, 60, 137-144.

62. Schmidt, M.; Wels, W. Targeted inhibition of tumour cell growth by a bispecific single-chain toxin containing an antibody domain and TGF alpha. Br. J. Cancer 1996, 74, 853-862.

63. Zenke, M.; Steinlein, P.; Wagner, E.; Cotten, M.; Beug, H.; Birnstiel, M.L. Receptor-mediated endocytosis of transferrin-polycation conjugates: an efficient way to introduce DNA into hematopoietic cells. Proc. Natl. Acad. Sci. USA 1990, 87, 3655-3659.

64. Maurer-Gebhard, M.; Schmidt, M.; Azemar, M.; Altenschmidt, U.; Stöcklin, E.; Wels, W.; Groner, B. Systemic treatment with a recombinant erbB-2 receptor-specific tumor toxin efficiently reduces pulmonary metastases in mice injected with genetically modified carcinoma cells. Cancer Res. 1998, 58, 2661-2666.

65. Kanatani, I.; Lin, X.; Yuan, X.; Manorek, G.; Shang, X.; Cheung, L.H.; Rosenblum, M.G.; Howell, S.B. Targeting granzyme B to tumor cells using a yoked human chorionic gonadotropin. Cancer Chemother. Pharmacol. 2011, 68, 979-990.

66. Bird, C.H.; Sun, J.; Ung, K.; Karambalis, D.; Whisstock, J.C.; Trapani, J.A.; Bird, P.I. Cationic sites on granzyme B contribute to cytotoxicity by promoting its uptake into target cells. Mol. Cell. Biol. 2005, 25, 7854-7867.

67. Shi, L.; Keefe, D.; Durand, E.; Feng, H.; Zhang, D.; Lieberman, J. Granzyme B binds to target cells mostly by charge and must be added at the same time as perforin to trigger apoptosis. J. Immunol. 2005, 174, 5456-5461.

68. Kurschus, F.C.; Fellows, E.; Stegmann, E.; Jenne, D.E. Granzyme B delivery via perforin is restricted by size, but not by heparan sulfate-dependent endocytosis. Proc. Natl. Acad. Sci. USA 2008, 105, 13799-13804.

69. Metkar, S.S.; Wang, B.; Aguilar-Santelises, M.; Raja, S.M.; Uhlin-Hansen, L.; Podack, E.; Trapani, J.A.; Froelich, C.J. Cytotoxic cell granule-mediated apoptosis: Perforin delivers granzyme B-serglycin complexes into target cells without plasma membrane pore formation. Immunity 2002, 16, 417-428.

70. Raja, S.M.; Metkar, S.S.; Honing, S.; Wang, B.; Russin, W.A.; Pipalia, N.H.; Menaa, C.; Belting, M.; Cao, X.; Dressel, R.; et al. A novel mechanism for protein delivery: Granzyme B undergoes electrostatic exchange from serglycin to target cells. J. Biol. Chem. 2005, 280, 20752-20761.

71. Kurschus, F.C.; Bruno, R.; Fellows, E.; Falk, C.S.; Jenne, D.E. Membrane receptors are not required to deliver granzyme B during killer cell attack. Blood 2005, 105, 2049-2058.

72. Estebanez-Perpina, E.; Fuentes-Prior, P.; Belorgey, D.; Braun, M.; Kiefersauer, R.; Maskos, K.; Huber, R.; Rubin, H.; Bode, W. Crystal structure of the caspase activator human granzyme B, a proteinase highly specific for an Asp-P1 residue. Biol. Chem. 2000, 381, 1203-1214.

73. Buzza, M.S.; Zamurs, L.; Sun, J.; Bird, C.H.; Smith, A.I.; Trapani, J.A.; Froelich, C.J.; Nice, E.C.; Bird, P.I. Extracellular matrix remodeling by human granzyme B via cleavage of vitronectin, fibronectin, and laminin. J. Biol. Chem. 2005, 280, 23549-23558. 
74. Tak, P.P.; Spaeny-Dekking, L.; Kraan, M.C.; Breedveld, F.C.; Froelich, C.J.; Hack, C.E. The levels of soluble granzyme A and B are elevated in plasma and synovial fluid of patients with rheumatoid arthritis (RA). Clin. Exp. Immunol. 1999, 116, 366-370.

75. Ronday, H.K.; van der Laan, W.H.; Tak, P.P.; de Roos, J.A.; Bank, R.A.; TeKoppele, J.M.; Froelich, C.J.; Hack, C.E.; Hogendoorn, P.C.; Breedveld, F.C.; et al. Human granzyme B mediates cartilage proteoglycan degradation and is expressed at the invasive front of the synovium in rheumatoid arthritis. Rheumatology (Oxford) 2001, 40, 55-61.

76. Skjelland, M.; Michelsen, A.E.; Krohg-Sorensen, K.; Tennoe, B.; Dahl, A.; Bakke, S.; Brosstad, F.; Damas, J.K.; Russell, D.; Halvorsen, B.; et al. Plasma levels of granzyme B are increased in patients with lipid-rich carotid plaques as determined by echogenicity. Atherosclerosis 2007, 195, e142-146.

77. Saito, Y.; Kondo, H.; Hojo, Y. Granzyme B as a novel factor involved in cardiovascular diseases. J. Cardiol. 2011, 57, 141-147.

78. Boivin, W.A.; Shackleford, M.; Vanden Hoek, A.; Zhao, H.; Hackett, T.L.; Knight, D.A.; Granville, D.J. Granzyme B cleaves decorin, biglycan and soluble betaglycan, releasing active transforming growth factor-beta1. PLoS One 2012, 7, e33163.

79. Wang, T.; Lee, M.H.; Choi, E.; Pardo-Villamizar, C.A.; Lee, S.B.; Yang, I.H.; Calabresi, P.A.; Nath, A. Granzyme B-induced neurotoxicity is mediated via activation of PAR-1 receptor and Kv1.3 channel. PLoS One 2012, 7, e43950.

80. Buzza, M.S.; Bird, P.I. Extracellular granzymes: Current perspectives. Biol. Chem. 2006, 387, 827-837.

81. Sun, J.; Bird, C.H.; Sutton, V.; McDonald, L.; Coughlin, P.B.; De Jong, T.A.; Trapani, J.A.; Bird, P.I. A cytosolic granzyme $\mathrm{B}$ inhibitor related to the viral apoptotic regulator cytokine response modifier A is present in cytotoxic lymphocytes. J. Biol. Chem. 1996, 271, 27802-27809.

82. Bird, C.H.; Sutton, V.R.; Sun, J.; Hirst, C.E.; Novak, A.; Kumar, S.; Trapani, J.A.; Bird, P.I. Selective regulation of apoptosis: The cytotoxic lymphocyte serpin proteinase inhibitor 9 protects against granzyme B-mediated apoptosis without perturbing the Fas cell death pathway. Mol. Cell. Biol. 1998, 18, 6387-6398.

83. Classen, C.F.; Bird, P.I.; Debatin, K.M. Modulation of the granzyme B inhibitor proteinase inhibitor 9 (PI-9) by activation of lymphocytes and monocytes in vitro and by Epstein-Barr virus and bacterial infection. Clin. Exp. Immunol. 2006, 143, 534-542.

84. Hirst, C.E.; Buzza, M.S.; Bird, C.H.; Warren, H.S.; Cameron, P.U.; Zhang, M.; Ashton-Rickardt, P.G.; Bird, P.I. The intracellular granzyme B inhibitor, proteinase inhibitor 9, is up-regulated during accessory cell maturation and effector cell degranulation, and its overexpression enhances CTL potency. J. Immunol. 2003, 170, 805-815.

85. Bots, M.; de Bruin, E.; Rademaker-Koot, M.T.; Medema, J.P. Proteinase inhibitor-9 expression is induced by maturation in dendritic cells via p38 MAP kinase. Hum. Immunol. 2007, 68, 959-964.

86. Medema, J.P.; de Jong, J.; Peltenburg, L.T.; Verdegaal, E.M.; Gorter, A.; Bres, S.A.; Franken, K.L.; Hahne, M.; Albar, J.P.; Melief, C.J.; et al. Blockade of the granzyme B/perforin pathway through overexpression of the serine protease inhibitor PI-9/SPI-6 constitutes a mechanism for immune escape by tumors. Proc. Natl. Acad. Sci. USA 2001, 98, 11515-11520. 
87. Rousalova, I.; Krepela, E.; Prochazka, J.; Cermak, J.; Benkova, K. Expression of proteinase inhibitor-9/serpinB9 in non-small cell lung carcinoma cells and tissues. Int. J. Oncol. 2010, 36, $275-283$.

88. ten Berge, R.L.; Meijer, C.J.; Dukers, D.F.; Kummer, J.A.; Bladergroen, B.A.; Vos, W.; Hack, C.E.; Ossenkoppele, G.J.; Oudejans, J.J. Expression levels of apoptosis-related proteins predict clinical outcome in anaplastic large cell lymphoma. Blood 2002, 99, 4540-4546.

89. van Houdt, I.S.; Oudejans, J.J.; van den Eertwegh, A.J.; Baars, A.; Vos, W.; Bladergroen, B.A.; Rimoldi, D.; Muris, J.J.; Hooijberg, E.; Gundy, C.M.; et al. Expression of the apoptosis inhibitor protease inhibitor 9 predicts clinical outcome in vaccinated patients with stage III and IV melanoma. Clin. Cancer Res. 2005, 11, 6400-6407.

90. Soriano, C.; Mukaro, V.; Hodge, G.; Ahern, J.; Holmes, M.; Jersmann, H.; Moffat, D.; Meredith, D.; Jurisevic, C.; Reynolds, P.N.; et al. Increased proteinase inhibitor-9 (PI-9) and reduced granzyme B in lung cancer: mechanism for immune evasion? Lung Cancer 2012, 77, 38-45.

91. Losasso, V.; Schiffer, S.; Barth, S.; Carloni, P. Design of human granzyme B variants resistant to serpin B9. Proteins 2012, 80, 2514-2522.

92. Sutton, V.R.; Sedelies, K.; Dewson, G.; Christensen, M.E.; Bird, P.I.; Johnstone, R.W.; Kluck, R.M.; Trapani, J.A.; Waterhouse, N.J. Granzyme B triggers a prolonged pressure to die in Bcl-2 overexpressing cells, defining a window of opportunity for effective treatment with ABT-737. Cell Death Dis. 2012, 3, e344.

93. Zhang, X.; Sawyer, G.J.; Dong, X.; Qiu, Y.; Collins, L.; Fabre, J.W. The in vivo use of chloroquine to promote non-viral gene delivery to the liver via the portal vein and bile duct. J. Gene Med. 2003, 5, 209-218.

94. Raynes, K. Bisquinoline antimalarials: their role in malaria chemotherapy. Int. J. Parasitol. 1999, 29, 367-379.

95. Zhao, J.; Zhang, L.H.; Jia, L.T.; Zhang, L.; Xu, Y.M.; Wang, Z.; Yu, C.J.; Peng, W.D.; Wen, W.H.; Wang, C.J.; et al. Secreted antibody/granzyme B fusion protein stimulates selective killing of HER2-overexpressing tumor cells. J. Biol. Chem. 2004, 279, 21343-21348.

96. Fominaya, J.; Wels, W. Target cell-specific DNA transfer mediated by a chimeric multidomain protein. Novel non-viral gene delivery system. J. Biol. Chem. 1996, 271, 10560-10568.

97. Uherek, C.; Fominaya, J.; Wels, W. A modular DNA carrier protein based on the structure of diphtheria toxin mediates target cell-specific gene delivery. J. Biol. Chem. 1998, 273, 8835-8841.

98. Antignani, A.; Youle, R.J. How do Bax and Bak lead to permeabilization of the outer mitochondrial membrane? Curr. Opin. Cell Biol. 2006, 18, 685-689.

99. Sampieri, K.; Fodde, R. Cancer stem cells and metastasis. Semin. Cancer Biol. 2012, 22, 187-193.

100. Robertson, M.J.; Cochran, K.J.; Cameron, C.; Le, J.M.; Tantravahi, R.; Ritz, J. Characterization of a cell line, NKL, derived from an aggressive human natural killer cell leukemia. Exp. Hematol. 1996, 24, 406-415.

101. Oberoi, P.; Jabulowsky, R.A.; Bähr-Mahmud, H.; Wels, W.S. Georg-Speyer-Haus, Frankfurt, Germany. 2013, unpublished work. 
102. Müller, T.; Uherek, C.; Maki, G.; Chow, K.U.; Schimpf, A.; Klingemann, H.G.; Tonn, T.; Wels, W.S. Expression of a CD20-specific chimeric antigen receptor enhances cytotoxic activity of NK cells and overcomes NK-resistance of lymphoma and leukemia cells. Cancer Immunol. Immunother. 2008, 57, 411-423.

(C) 2013 by the authors; licensee MDPI, Basel, Switzerland. This article is an open access article distributed under the terms and conditions of the Creative Commons Attribution license (http://creativecommons.org/licenses/by/3.0/). 